\title{
Too old for technology?
}

Citation for published version (APA):

Lourenço de Oliveira Mariano, J. M. (2021). Too old for technology? age stereotypes and technology use by older adults. [Doctoral Thesis, Maastricht University]. Maastricht University.

https://doi.org/10.26481/dis.20211102jm

Document status and date:

Published: 01/01/2021

DOI:

10.26481/dis.20211102jm

Document Version:

Publisher's PDF, also known as Version of record

\section{Please check the document version of this publication:}

- A submitted manuscript is the version of the article upon submission and before peer-review. There can be important differences between the submitted version and the official published version of record.

People interested in the research are advised to contact the author for the final version of the publication, or visit the DOI to the publisher's website.

- The final author version and the galley proof are versions of the publication after peer review.

- The final published version features the final layout of the paper including the volume, issue and page numbers.

Link to publication

\footnotetext{
General rights rights.

- You may freely distribute the URL identifying the publication in the public portal. please follow below link for the End User Agreement:

www.umlib.nl/taverne-license

Take down policy

If you believe that this document breaches copyright please contact us at:

repository@maastrichtuniversity.nl

providing details and we will investigate your claim.
}

Copyright and moral rights for the publications made accessible in the public portal are retained by the authors and/or other copyright owners and it is a condition of accessing publications that users recognise and abide by the legal requirements associated with these

- Users may download and print one copy of any publication from the public portal for the purpose of private study or research.

- You may not further distribute the material or use it for any profit-making activity or commercial gain

If the publication is distributed under the terms of Article $25 \mathrm{fa}$ of the Dutch Copyright Act, indicated by the "Taverne" license above, 


\section{Summary}

Information and communication technology holds great promise in supporting the growing population of older people. Yet, older adults are less likely to use technology compared to the general population. This digital exclusion not only prevents them from taking advantage of its potential benefits, but also limits their ability to live independently in an increasingly digital world. Besides being commonly stereotyped as less technologically competent than younger age groups, older adults often mention their age or being "too old" as reasons for not using technology. Surprisingly, the potential influence of stereotypical perceptions about older people and the aging process on older adults' use behaviours remains largely understudied. This work aimed to fill this gap by investigating whether and how age stereotypes determine technology use in late adulthood. To this end, we independently tested the predictions of two major theoretical approaches to the effects of stereotypes on behaviours: stereotype threat and stereotype embodiment.

According to stereotype threat theory, the fear of confirming negative stereotypes associated with their age group may lead older adults to avoid using technology. We examined the relationship between stereotype threat and technology use across three studies conducted as part of two applied projects in the aging field. As expected, higher levels of stereotype threat were associated with lower rates of technology use (Studies 1 to 3). This was shown using longitudinal (Study 1) and cross-sectional (Studies 2 and 3) designs, objective (Study 3) and subjective (Studies 1 and 2) behavioural measures, and across different types of technology, namely desktop and laptop computer use (Studies 1 and 2), tablet use (Study 3), and internet use (Study 2). In line with the technology acceptance model, this relationship was mediated more distally by anxiety (Study 3) and perceived ease of use (Studies 2 and 3) and more proximally by perceived usefulness and behavioural intention (Studies 2 and 3).

In turn, as implied by stereotype embodiment theory, the internalization of negative age stereotypes endorsed earlier in life into negative self-perceptions of aging later in life may deter older adults from using technology. We examined the relationship between self-perceptions of aging and technology use across three studies based on secondary data from the Health and Retirement Study and the German Ageing Survey. As predicted, more positive self-perceptions of aging were associated with higher levels of technology use and cognitive functioning mediated this relationship (Studies 4 to 6). Self-perceptions of aging, both more general 
(Studies 4 and 5) and more specific to competence (Study 6), were positively linked to general computer use (Studies 4 and 5) and specific internet uses (Study 6). This was shown using longitudinal designs (Studies 4 to 6), samples from the United States (Study 4) and Germany (Studies 5 and 6), and over time intervals of eight (Study 4) and three years (Studies 5 and 6).

By confirming the assumptions of both theories, these findings suggest that age stereotypes determine technology use in late adulthood through distinct, yet complementary processes. Future studies should further explore these effects by integrating both theoretical approaches. Interventions and policies promoting positive intergenerational contact and positive views on age and aging should thus contribute to the digital inclusion of older adults. 